\title{
Site preference of myxosporean spp. on the fins of some Hungarian fish species
}

\author{
Kálmán Molnár* \\ Veterinary Medical Research Institute, Hungarian Academy of Sciences, PO Box 18, 1581 Budapest, Hungary
}

\begin{abstract}
Some species of the known fish myxosporeans select fins as type location for their development. During the plasmodial development of Myxobolus, Henneguya and Thelohanellus species in cyprinid fishes and eels, 3 main locations of plasmodial development were distinguished inside the fins. M. portucalensis, M. alburni, M. caudatus and a Myxobolus sp. formed plasmodia in the dermis of the skin doublets between finrays, while plasmodia of $M$. diversus and $H$. cutanea developed inside the lumen of the cartilaginous finrays. The third type of development was represented by $T$. nikolskii, which started its development on the outer surface of the finrays. Plasmodia both in the lumen and on the surface of the finrays were surrounded by a cartilaginous capsule, but plasmodia of $T$. nikolskii also had a thick connective tissue capsule containing pieces of cartilage.
\end{abstract}

KEY WORDS: Myxosporea $\cdot$ Plasmodia $\cdot$ Site preference $\cdot$ Fish $\cdot$ Fins

Resale or republication not permitted without written consent of the publisher

\section{INTRODUCTION}

The fin is one of the most common sites of establishment of various myxosporean species infecting fishes. In most cases, parasites colonising the fin occupy well-defined locations. Some of them show preference for the dermis of the fins while others form plasmodia on the cartilaginous finrays or fin vasculature. In the specialist literature, fins are referred to as only one of the possible sites of establishment; the relevant monographs (Shulman 1966, Donec \& Shulman 1984, Lom \& Dyková 1992) sometimes list several organs other than the fins as sites of establishment for a given myxosporean species. Molnár (1994) has suggested that myxosporeans have certain host-, organ- and tissue-specificity, the last-mentioned being the most important. The fin is an organ of rather simple structure, composed of epithelial, connective tissue endothelial elements and the chondrifying collagenous substance of the finrays (Lanzing 1976, Becerra et al. 1983, Brandstatter et al. 1990, Sharples \& Evans 1996). However, because of their different tissue affinities,

*E-mail: kalman@vmri.hu myxosporeans can occur in diverse locations even within this relatively simply structured organ.

This paper describes the most characteristic types of establishment and development of myxosporean plasmodia in the fins on the basis of experience gained with Myxobolus, Henneguya and Thelohanellus species.

\section{MATERIALS AND METHODS}

Records involving infections of fins with myxosporean parasites throughout a $7 \mathrm{yr}$ period were evaluated, and the site selection of different species typified. Preparations were selected from the author's histological collection made during that period on fish myxosporeans. Histological sections were made from the fins of various fish species infected with different developmental stages of Myxobolus, Henneguya and Thelohanellus species, but some uninfected fish were also examined as controls. Samples were collected from 7 fish species: common carp Cyprinus carpio, goldfish Carassius auratus, barbel Barbus barbus, common bream Abramis brama, roach Rutilus rutilus, bleak Alburnus alburnus and eel Anguilla anguilla. In order to ensure 
a good plane for sectioning, the fins (primarily the tail fin), of infected fishes were cut off close to the base, gently placed flat under a coverslip, and soaked for 5 min in some drops of Bouin's solution. After the fins became rigid they were transferred into bottles and fixed for $4 \mathrm{~h}$ in approx. $20 \mathrm{ml}$ of Bouin's solution. The fins were embedded in paraffin wax and some sections were cut longitudinally in the plane of the fins, while others were cut transversally. Sections of 4 to $8 \mu \mathrm{m}$ thickness were stained with haematoxylin and eosin and by the Farkas-Mallory method (Kiszely \& Barka 1958). Microphotographs were prepared with video equipment attached to an Olympus microscope to obtain digitised pictures (Székely 1997).

\section{RESULTS}

\section{Anatomical and histological structure of the fins in uninfected cyprinids}

The calcified finrays or lepidotrichia are segmented along their length with segments joined to each other by ligaments at the intersegmental joints (Fig. 1). Each lepidotrichium consists of $2 \mathrm{v}$-shaped or w-shaped cartilaginous rods (hemisegments), with an open space laterally (Fig. 2). The neighbouring finrays are connected by interlepidotrichial ligaments. The hemisegments are covered both outside and inside by a single dense connective tissue layer functioning as perichondral cells. These cells produce the extracellular collagenous material of the finrays, which gradually

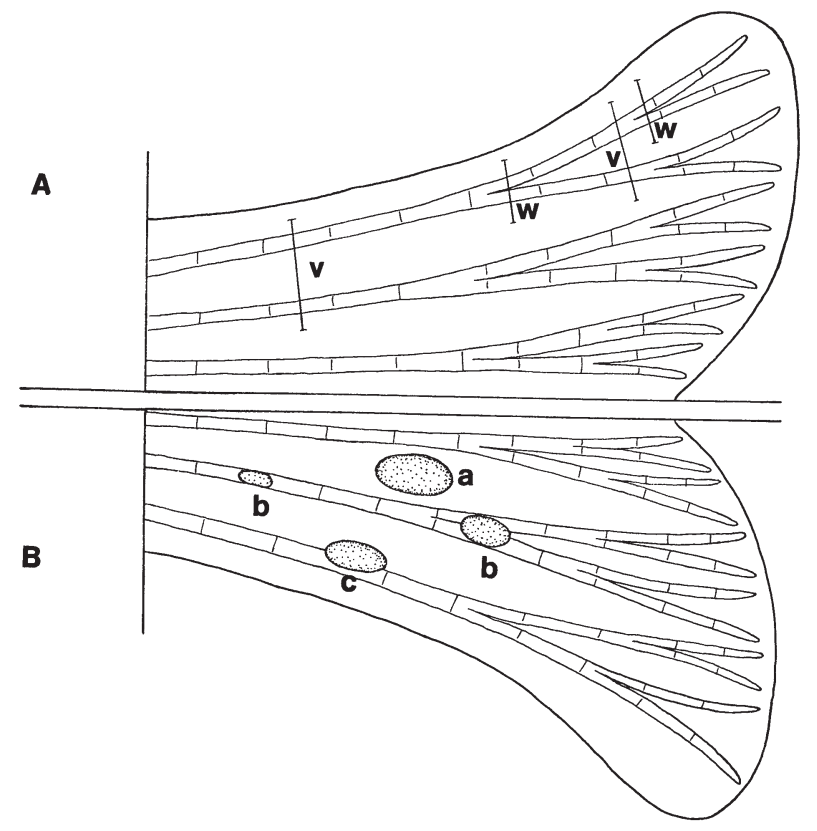

Fig. 1. Schematic illustration of the structure of a cyprinid tail fin. (A) Uninfected fin (bar v: cross-sections with v-shaped hemisegments; bar w: cross-sections with w-shaped hemisegments); (B) possible locations of myxosporean plasmodia (a: plasmodium in the interlepidotrichial region; b: plasmodium inside the lumen of the hemisegments; c: plasmodium on the surface of the hemisegment)

becomes calcified. The lumen of the finrays (intrasegmental region) is filled up by a loose connective tissue rich in blood vessels and nerves (Fig. 3). Major blood vessels and nerves run through the interlepi-
A

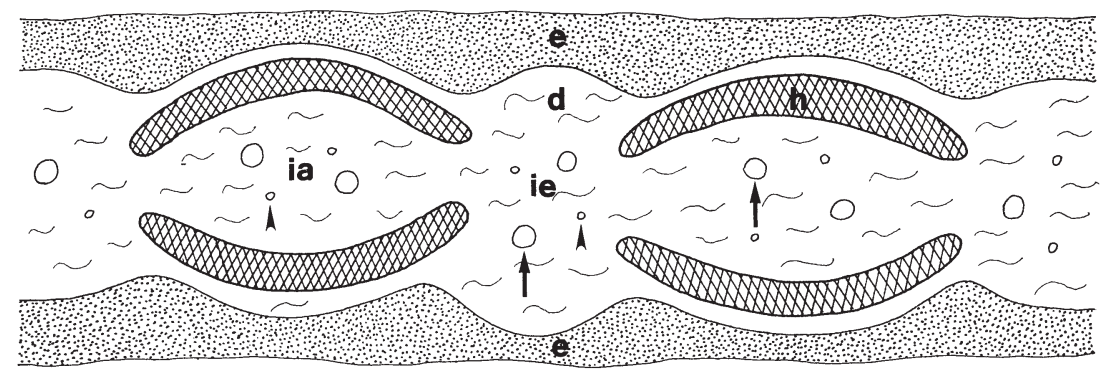

$\mathbf{B}$

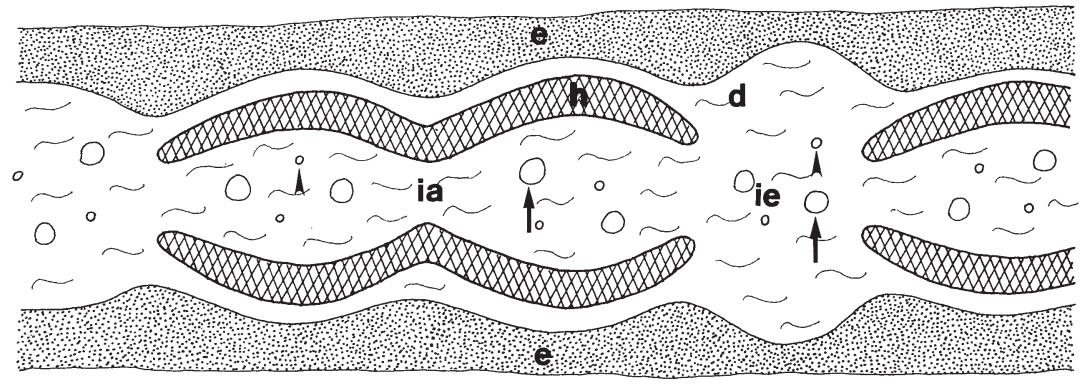

Fig. 2. Diagram of a cross-sectioned tail fin. (A) Cross-section with V-shaped hemisegments in an undivided part of the finray; (B) cross-section with w-shaped hemisegments at a dividing part of the finray. e: epidermis; d: dermis; h: hemisegments; ie: interlepidotrichial region; ia: intrasegmental region; arrows: blood vessels; arrowheads: nerves 
dotrichial region. The dermis of the skin over the finrays is relatively thin and comprises a fibrous connective tissue. Between the dermis and the stratified squamous epithelium a distinct eosinophilic basal lamina is located. The basal lamina (basement membrane) is generally thicker in the interlepidotrichial region than adjacent to the hemisegments (Figs. 4 \& 6).

\section{Alterations in fins caused by myxosporean plasmodia}

During these studies, myxosporean infections were consistently found in the fins of 7 fish species. The observed infections occurred in 3 typical locations in the fins, primarily in the tail fins:

Plasmodial development in skin doublets between the finrays

In 4 of the 7 cases, myxosporean plasmodia developed in the loose connective tissue layer of the skin doublets between the finrays. Such site selection was observed in Myxobolus portucalensis infection of the eel (Fig. 4), M. alburni infection of the bleak (Fig. 5), $M$. caudatus infection of the barbel (Fig. 6) and Myxobolus sp. infection of the roach (Fig. 7). In these infections no signs of host reaction could be seen around the plasmodia, the cysts were located freely in the dermis, and at most a closer contact of host cells could be observed due to the pressure exerted by the plasmodium on its environment.

Plasmodial development inside lumen of the finrays

Development inside the finrays was observed in 2 fish species. The plasmodia of Henneguya cutaea (Fig. 8) in common bream and those of Myxobolus diversus (Fig. 9) in goldfish developed equally inside the lumen of the 2 hemisegments constituting the cartilaginous finrays. The relatively large plasmodia completely filled the space formed by the hemisegments, pushing the blood vessels and nerves running between them to the periphery, close to the cartilage of the hemisegments, but they did not cause morphological changes in the substance of the cartilage. Simultaneously, the larger plasmodia bulged into the intersegmental joints and the interlepidotrichial connective tissue. The ectoplasm of the plasmodia of both species was bordered by a cartilaginous collagenous capsule surrounded by a flattened cell layer of dense connective tissue. This cell layer, functioning as perichondral cells, formed the host-derived cartilaginous capsule of the plasmodia.
Plasmodial development on outer surface of the finrays

The third type of fin-parasitic myxosporeans is represented by Thelohanellus nikolskii, which forms plasmodia of substantial size (1 to $5 \mathrm{~mm}$ in diameter) on the surface of the fins of common carp (Fig. 10). The development of this parasite is also associated with the cartilaginous layer of the finrays; however, the plasmodia start their development on the outer surface, rather than inside the lumen, of the hemisegments. Unlike the 2 species developing inside the lumen of the hemisegments, T. nikolskii markedly deforms the cartilaginous substance of the finrays, and its plasmodia are surrounded by a relatively thick cartilaginous capsule formed by the perichondral cells and also by a similarly thick connective tissue capsule. A further characteristic feature of this infection is that the developing plasmodium substantially changes the structure of the hemisegments. Under the developing plasmodium the cartilaginous substance of the hemisegments undergoes deformation and breaks up into small fragments. Small pieces of the disintegrated hemisegment can be found, as small cartilaginous islets, in the wall of the connective tissue capsule surrounding the plasmodium (Fig. 10).

\section{DISCUSSION}

The teleost fin is one of the most common sites of establishment of eukaryotic parasites and possibly of other pathogens. Of the pathogens visible to the naked eye or by light microscopy at low magnification, monogeneans and trematode larvae belonging to metazoan organisms occurring most frequently on the fins, but certain representatives of microsporeans, some Dermocystidium species of still uncertain taxonomic position, and the lymphocystis disease virus also form distinct nodules (Reichenbach-Klinke 1950, Schäperclaus 1954, Roberts 1978, Bauer et al. 1981, Lom \& Dyková 1992). Numerous myxosporeans, including the Мухоbolus, Henneguya and Thelohanellus species of cyprinids studied in this work, can colonise the fins of fishes. Although the occurrence of myxosporeans on fins has been known for a long time, few reports have indicated the fin as a typical site of infection. Schubert (1967) described the species $H$. pinnae from the fins of the tropical fish species Ctenopoma kingsleyae, and subsequently studied that parasite by electron microscope methods (Schubert 1968). Minchew (1977) found a species in American catfish in a typical location (in the adipose fin) and named it Henneguya adiposa. The most common fin parasite (T. nikolskii) in carp farms was studied by Molnár (1982). The grasscarp parasite $M$. pinna Wu et Chen, 1987 (Chen \& Ma 1998) seems also to be a 

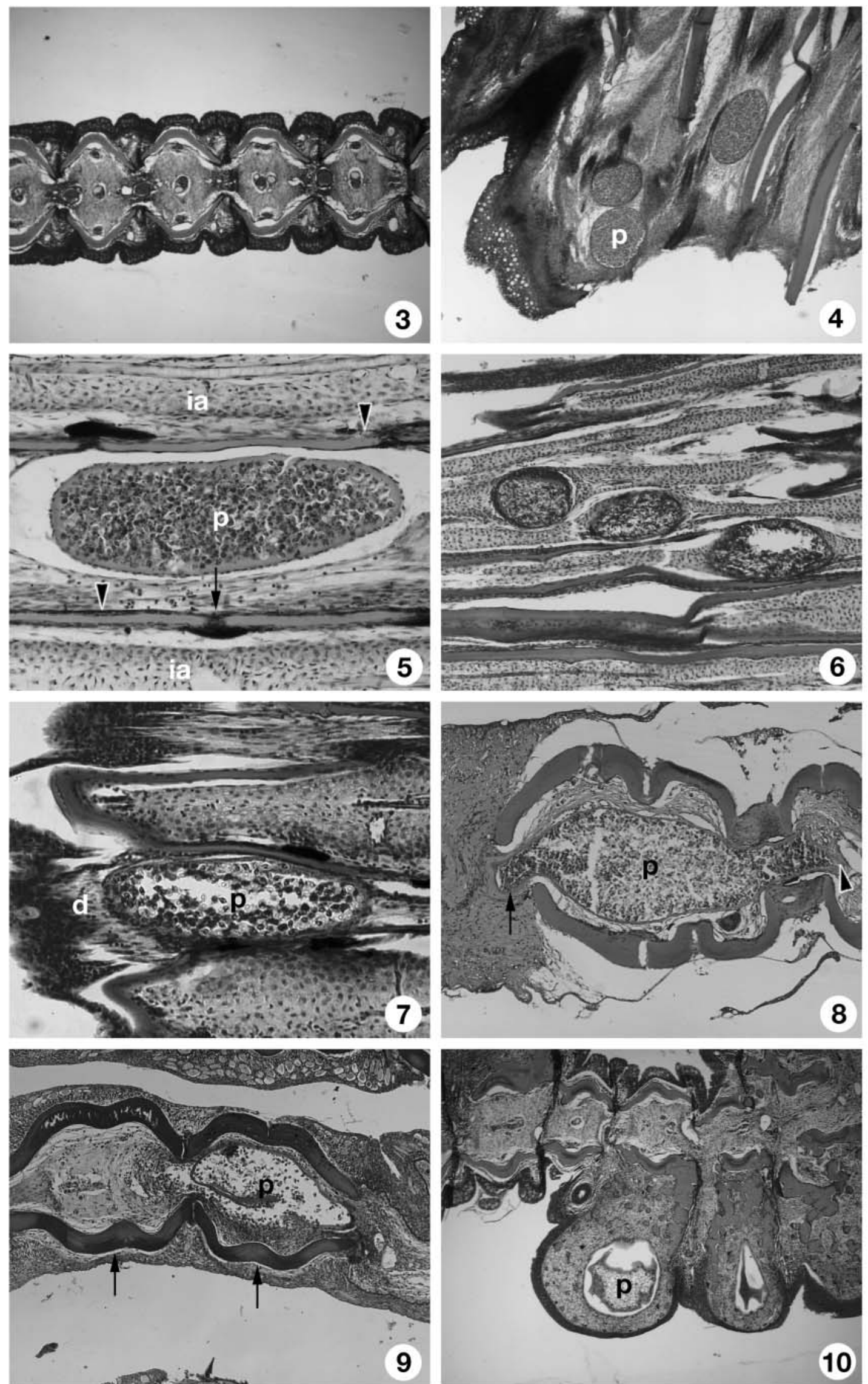
Figs. 3-10. Fig. 3. Cross-section of an uninfected tail fin of the common carp Cyprinus carpio close to the base; finrays are located

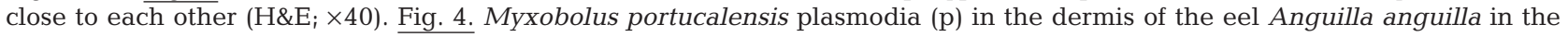
interlepidotrichial region of the tail fin $(\mathrm{H \& E} ; \times 80)$. Fig. 5. Myxobolus alburni plasmodium $(\mathrm{p})$ in the dermis of the tail fin of the bleak Alburnus alburnus between 2 finrays (arrowheads) in the level of the intersegmental joints (arrow); the intrasegmental regions (ia) of the finrays are seen on both sides $\left(\mathrm{H} \& \mathrm{E}_{;} \times 160\right)$. Fig. 6. Interlepidotrichial plasmodia of Myxobolus caudatus in the tail fin of the barbel Barbus barbus $(\mathrm{H \& E} ; \times 80)$. Fig. 7. Myxobolus sp. in the tail fin of a roach Rutilus rutilus; the plasmodium (p) is located in the dermis $(\mathrm{d})$ between 2 finrays $\left(\mathrm{H} \& \overline{\mathrm{E}_{i} \times 16}\right)$. Fig. 8. Plasmodium (p) of Henneguya cutanea in the lumen of the finray of the common bream Abramis brama; the plasmodium fills only a part of the intrasegmental region, but bulges into the interlepidotrichial region (arrow) and into the lumen of the neighbouring finray (arrowhead) (H\&E, ×160). Fig. 9. Myxobolus diversus plasmodium (p) in the lumen of one of the dividing finrays in the goldfish Carassius auratus (arrows) (H\&E, $\times 160$ ). Fig. 10. Plasmodia (p) of Thelohanellus nikolskii on the surface of the finrays of the common carp C. carpio; the cartilage structure of the hemisegments is deformed, the thick connective tissue capsule contains cartilaginous islets $\left(\mathrm{H} \& \mathrm{E}_{;} \times 40\right)$

typical parasite of the finrays. The fin has been reported to be the typical site of infection for the eel parasite $M$. portucalensis, and for $M$. alburni parasitising the bleak, a cyprinid fish (Saraiva \& Molnár 1990, Molnár 2000). Despite the common occurrence of fin infections, data on such infections are relatively scarce in the literature. This is probably due to the fact that infection of the fins, which are non-vital organs, is not a direct cause of mortality.

Studying the host-, organ- and tissue-specificity of different myxosporean species, Molnár (1996) concluded that they were strictly tissue-specific, and that most were characterised by location in a certain organ. Site selection is primarily determined by the tissuespecificity. Species developing in tissues that occur at various sites in the body (skeletal muscle, connective tissue) are not characterised by organ-specificity, and therefore they may be present in different parts of the body. The muscle-parasitic Kudoa and Myxobolus species belong to this group. Kabata \& Whitaker (1981) detected $K$. thyrsites and $K$. paniformis in different skeletal muscle sites, and the intracellular plasmodia of the muscle-parasitic $M$. cyprini and $M$. artus were also found to occur in different parts of the body (Molnár \& Kovács-Gayer 1985, Ogawa et al. 1992). Like muscle-parasitic species, myxosporeans displaying affinity to the loose connective tissue are also characterised by a lack of organ-specificity; of these, the plasmodia of Thelohanellus hovorkai have been detected in the head, in the intermuscular tissues and in the tissues around the intestine by Molnár \& KovácsGayer (1986) and by Yokoyama et al. (1998).

Organ-specific and cosmopolitan species occur equally among those species developing in the capillaries and blood vessels. The eel parasite Myxidium giardi may form plasmodia in the renal capillaries, in the blood vessels of the gills, and even in the skin (Lom \& Dyková 1992). At the same time, numerous gill-parasitic myxosporean species are characterised by strict site selection: some species form plasmodia in the capillaries of the gill lamellae, while others exhibit preference for the gill arteries. The widely varying forms of gill colonisation by myxosporeans have been described in detail by Paperna (1973), Sakiti et al. (1991) and Molnár (2002). Typical examples of strictly organspecific parasites are myxosporeans with an affinity to cartilage. Myxobolus cerebralis is a parasite of the cartilage matrix of the head and vertebral column (Halliday 1973), while the primary site of colonisation for $M$. cartilaginis is the cartilage substance of the branchial arches (Hoffman et al. 1965).

The fin is an organ of relatively simple structure, the most characteristic part of which is constituted by the finrays formed from calcifying collagen substance. Of the examples cited in the present paper, the development of Myxobolus diversus, Henneguya cutanea and Thelohanellus nikolskii is associated with the presence of that collagen substance. All 3 species are typical fin parasites, and their plasmodia are surrounded by a 'cartilaginous capsule' formed from that collagen. It is obvious that in the above cases the site selection of the fin parasites is determined by the tissue structure of the finray. This fact does not conflict with the fact that Moshu \& Molnár (1997) found the plasmodia of $T$. nikolskii also on the as yet non-calcified edge of the scales. This latter occurrence of the parasite indicates only that tissue specificity takes priority over organspecificity, as scales are formed from a similar collagenous substance to that constituting the finrays.

While, however, species developing in or on the finrays are uniformly characterised by an affinity to connective tissue consisting of collagenic fibres, the plasmodia formed in the connective tissue of the skin doublets between the finrays have no such affinity. It is undoubtedly true that the 4 type species Myxobolus portucalensis, M. caudatus, Myxobolus sp. (from roach) and M. alburni all develop their plasmodia in the subcuticular connective tissue of the fins; however, the available histopathological results are not sufficient to decide whether the plasmodia buds actually start developing in association with connective tissue cells or within one of the small capillaries. Although a cosmopolitan location would be conceivable both in the former and in the latter case, the observations made so far are suggestive of a strict fin-associated site selection. 
Of the species occurring in the 3 different fin locations described in this paper, the species developing in the dermis of the skin doublets between the finrays can clearly be regarded as myxosporeans with an affinity for the connective tissue, although it cannot be excluded that they start developing within the lumen of a fin capillary. The species developing within the lumen of the finrays are likely to have a similar intracapillary type of development, although in their case the cartilaginous capsule formed around the plasmodium suggests that perichondral collagen-forming cells may play a fundamental role in their development, primarily in the formation of the plasmodial wall, in the same way as in Thelohanellus nikolskii.

Acknowledgements. K.M. thanks Dr. Csaba Székely for his help in preparing digitised photos. Thanks are due to Dr. Ferenc Baska and Györgyi Ostoros for their help with the histological work. The study was rendered possible by a grant from the Hungarian Scientific Research Fund (project nos. T 029200 and T 031755) and by financial support received from the Fish Management Fund of the Ministry of Agriculture and Rural Development.

\section{LITERATURE CITED}

Bauer ON, Musselius VA, Strelkov JA (1981) Diseases of pond fishes. Publishing House Legkhaya i Pishchevaya Promishlennost, Moscow (in Russian)

Becerra J, Montes GS, Bexiga SRR, Junqueira LCU (1983) Structure of the tail fin in teleosts. Cell Tissue Res 230: 127-137

Brandstätter R, Misof B, Pazmandi C, Wagner GP (1990) Microanatomy of the pectoral fin in blennies (Blenniini, Blennioidea, Teleostei). J Fish Biol 37:729-743

Chen C, Ma C (1998) Myxozoa: Myxosporea. Fauna Sinica. Science Press, Beijing (in Chinese)

Donec ZS, Shulman SS (1984) Parasitic protozoa. In: Bauer ON (ed) Key to the parasites of freshwater fish of the USSR, Vol 1. Nauka, Leningrad, p 88-251 (in Russian)

Halliday MM (1973) Studies on Myxosoma cerebralis, a parasite of salmonids. II. The development and pathology of Myxosoma cerebralis in experimentally infected rainbow trout (Salmo gairdneri) fry reared at different water temperature. Nord Vetmed 25:349-358

Hoffman GL, Putz RE, Dunbar CE (1965) Studies on Myxosoma cartilaginis n. sp. (Protozoa: Myxosporidea) of centrarchid fish and a synopsis of the Myxosoma of NorthAmerican freshwater fishes. J Protozool 12:319-332

Kabata Z, Whitaker DJ (1981) Two species of Kudoa (Myxosporea: Multivalvulida) parasitic in the flesh of Merlucius productus (Ayres, 1855) (Pisces: Teleostei) in the Canadian Pacific. Can J Zool 59:2085-2092

Kiszely Gy, Barka T (1958) Practical microtechnic and histochemistry. Kossuth, Budapest (in Hungarian)

Lanzing WJR (1976) The fine structure of fins and finrays of Tilapia mossambica (Peters). Cell Tissue Res 173:349-356

Lom J, Dyková I (1992) Protozoan parasites of fishes. Elsevier, Amsterdam

Minchew CD (1977) Five new species of Henneguya (Proto- zoa: Myxosporida) from ictalurid fishes. J Protozool 24: $213-220$

Molnár K (1982) Biology and histopathology of Thelohanellus nikolskii Achmerov, 1955 (Myxosporea, Myxozoa), a protozoan parasite of the common carp (Cyprinus carpio). Z Parasitenkd 68:269-277

Molnár K (1994) Comments on the host, organ and tissue specificity of fish myxosporeans and on the types of their intrapiscine development. Parasitol Hung 27:5-20

Molnár K (2000) Survey on Myxobolus infection of the bleak (Alburnus alburnus L.) in the River Danube and in Lake Balaton. Acta Vet Hung 48:421-432

Molnár K (2002) Site preference of fish myxosporeans in the gill. Dis Aquat Org 48:194-207

Molnár K, Kovács-Gayer É (1985) The pathogenicity and development within the host fish of Myxobolus cyprini Doflein, 1998. Parasitology 90:549-555

Molnár K, Kovács-Gayer É (1986) Biology and histopathology of Thelohanellus hovorkai Akhmerov, 1960 (Myxosporea, Myxozoa), a protozoan parasite of the common carp (Cyprinus carpio). Acta Vet Hung 34:67-72

Moshu A, Molnár K (1997) Thelohanellus (Myxozoa: Myxosporea) infection of the scales in the European wild carp Cyprinus carpio carpio. Dis Aquat Org 28:115-123

Ogawa K, Delgahapitiya K P, Furuta T, Wakabayashi H (1992) Histological studies on the host response to Myxobolus artus Akhmerow, 1960 (Myxozoa, Myxobolidae) infection in the skeletal muscle of the carp. J Fish Biol 41:363-371

Paperna I (1973) Occurrence of Cnidospora infections in freshwater fishes in Africa. Bull Inst Fr Afr Noire (Sér A) 35:509-521

Reichenbach-Klinke HH (1950) Der Entwicklungkreis der Dermocystidien sowie Beschreibung einer neuen Haplosporidien Art Dermocystidium percae n. sp. Verh Dtsch Zool Ges 1949:126-132

Roberts RJ (1978) Fish pathology. University Press, Aberdeen

Sakiti N, Blanc É, Marques A, Bouix G (1991) Myxosporidies (Myxozoa, Myxosporea) du genre Myxobolus Bütschli, 1882 parasites de poissons Cichlidae du lac Nokoué au Bénin (Afrique de l'Ouest). J Afr Zool 1:173-186

Saraiva A, Molnár K (1990) Myxobolus portucalensis n. sp. in the fins of European eel Anguilla anguilla (L.) in Portugal. Rev Iber Parasitol 50:31-35

Schäperclaus W (1954) Fischkrankheiten. Akademie Verlag, Berlin

Schubert G (1967) Henneguya pinnae n. sp. (Sporozoa, Myxosporidea, Myxobolidae) aus den Flossen von Ctenopoma kingsleyae (Osteoichthyes, Anabatidae). Z Parasitenkd 29: 299-303

Schubert G (1968) Elektronmikroskopische Untersuchungen zur Sporenentwicklung von Henneguya pinnae Schubert (Sporozoa, Myxosporidea, Myxobolidae). Z Parasitenkd 30: $57-77$

Sharples AD, Evans CW (1996) Pathology of fin erosion in goldfish (Carassius auratus). Dis Aquat Org 24:81-91

Shulman SS (1966) Myxosporidia of the fauna of the USSR. Nauka, Moscow (in Russian)

Székely Cs (1997) Possible applications of video technology and digital image processing in fish parasitology: morphological examination of the groups Apicomplexa and Myxosporea-Actinosporea by video technology. Bull Eur Assoc Fish Pathol 17:81-82

Yokoyama H, Liyanage, YS, Sugai A, Wakabayashi H (1998) Hemorrhagic thelohanellosis of color carp caused by Thelohanellus hovorkai (Myxozoa: Myxosporea). Fish Pathol 33: 85-89

Submitted: February 13, 2002; Accepted: July 17, 2002

Proofs received from author(s): October 31, 2002 